\title{
Article \\ Herbicide in Weed Management of Wheat (Triticum aestivum L.) and Rainy Season Rice (Oryza sativa L.) under Conservation Agricultural System
}

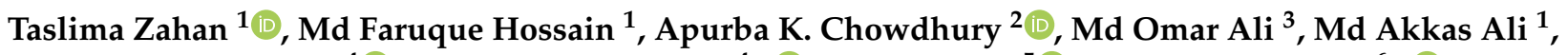 \\ Eldessoky S. Dessoky ${ }^{4}\left(\mathbb{D}\right.$, Mohamed M. Hassan ${ }^{4, *(\mathbb{D})}$, Sagar Maitra ${ }^{5}$ and Akbar Hossain ${ }^{6, *(D)}$ \\ 1 On-Farm Research Division (OFRD), Bangladesh Agricultural Research Institute (BARI), Joydebpur, \\ Gazipur 1701, Bangladesh; taslimazahan_tzp@yahoo.com (T.Z.); faruque1969@yahoo.com (M.F.H.); \\ akkasbari@gmail.com (M.A.A.) \\ 2 Seed Technology Division, BARI, Joydebpur, Gazipur 1701, Bangladesh; apurba.chowdhury@gmail.com \\ 3 Pulse Crop Research Sub-Centre, BARI, Joydebpur, Gazipur 1701, Bangladesh; omaraliprc@gmail.com \\ 4 Department of Biology, College of Science, Taif University, Taif 21944, Saudi Arabia; es.dessouky@tu.edu.sa \\ 5 Department of Agronomy, Centurion University of Technology and Management, Alluri Nagar 761211, India; \\ sagar.maitra@cutm.ac.in \\ 6 Bangladesh Wheat and Maize Research Institute, Dinajpur 5200, Bangladesh \\ * Correspondence: m.khyate@tu.edu.sa (M.M.H.); akbarhossainwrc@gmail.com (A.H.)
}

\section{check for}

updates

Citation: Zahan, T.; Hossain, M.F.; Chowdhury, A.K.; Ali, M.O.; Ali, M.A.; Dessoky, E.S.; Hassan, M.M.; Maitra, S.; Hossain, A. Herbicide in Weed Management of Wheat (Triticum aestivum L.) and Rainy Season Rice (Oryza sativa L.) under Conservation Agricultural System. Agronomy 2021, 11, 1704. https:// doi.org/10.3390/agronomy11091704

Academic Editor: Stéphane Cordeau

Received: 10 June 2021

Accepted: 24 August 2021

Published: 26 August 2021

Publisher's Note: MDPI stays neutral with regard to jurisdictional claims in published maps and institutional affiliations.

Copyright: (c) 2021 by the authors. Licensee MDPI, Basel, Switzerland. This article is an open access article distributed under the terms and conditions of the Creative Commons Attribution (CC BY) license (https:// creativecommons.org/licenses/by/ $4.0 /)$.
Abstract: Conservation agriculture (CA) based practices are gaining popularity in smallholder farming systems recently because they ensure soil quality and soil health, and they also reduce the total cultivation costs. However, weeds are a major hinderance to achieving the desired yield of crops in cereal-based cropping systems under CA-based practices. Proper weed management is a big challenge for crop growers to reduce the labor demand and cost of production. Considering these burning issues, a field study was done with a CA-based rice-wheat-mung bean (Vigna radiata L.) cropping pattern in two consecutive years (2017-2018 and 2018-2019). The study aimed to understand the types and distribution of weeds in non-puddled rice fields and also in strip-planted wheat fields in sandy loam textured soil with low organic matter $(0.87 \%)$ content. Furthermore, we also tried to discover the most economic and effective ways to manage weeds in both cereals of the cropping pattern. The performance of two herbicides-pendimethalin (as pre-emergence) and carfentrazone-ethyl + isoproturon (as post-emergence)—for strip-planted wheat and three herbicides-two pre-emergence herbicides pretilachlor and pyrazosulfuron-ethyl as well as one post-emergence herbicide, bispyribac-sodium-for non-puddled rainy season rice were evaluated, where the 'weedy check' and 'weed free' treatments were considered as a control. In a two-year field experiment, eight weed species in the strip-planted wheat field during the first year and fourteen species in the second year were identified. Among them, three grasses such as Cynodon dactylon (L.) Pers., Digitaria sanguinalis (L.) Scop. and Echinochloa colona (L.) Link and one broadleaf weed Physalis heterophylla (L.) Nees, were found to the dominant in both years. During the first season, the dominant weed species in strip-planted wheat was Physalis heterophylla (L.); Digitaria sanguinalis (L.) Scop was dominant in the second year. In a non-puddled field of rainy season rice, eleven weed species were found in the first year and twelve species were found in the second year. Among the weed species, four types of grasses (Cynodon dactylon (L.) Pers., Leptochloa chinensis (L.) Nees, Echinochloa colona (L.) Link and Leersia hexandra (Sw.), one sedge (Fimbristylis miliacea (L.) Vahl) and four broadleaf weed species (Ludwigia decurrens (Walter), Jussiaea repens (L.), Enhydra fluctuans (Lour) and Alternanthera sessilis (L.) R.Br. ex DC.) were found the common in both years. The most dominant weed in non-puddled rainy season rice was Leptochloa chinensis (L.) for the first year and Alternanthera sessilis (L.) for the second year. The study revealed that the sequential application of pendimethalin as pre-emergence treatment followed by carfentrazone-ethyl + isoproturon as post-emergence treatment were most effective and economically viable for weed control in strip-till wheat because they achieved the highest grain and straw yields. For weed management in nonpuddled rainy season rice, the herbicide pyrazosulfuron-ethyl applied as pre-emergence treatment 
and bispyribac-sodium as the post-emergence application were found to be the most effective combination to obtain a desirable yield.

Keywords: cereal based cropping system; weeds; herbicides; economics; climate-smart agriculture

\section{Introduction}

Conservation agriculture (CA) is a package of environmentally friendly technology that is grounded based on three basic principles such as minimum soil disturbance, crop residue retention and crop rotation [1]. The CA helps to improve soil quality [2-4] and health $[5,6]$ and also to sustain crop productivity [7]. Soil health represents a consolidative character that replicates the capability of soils to support agricultural practices sustainably $[8,9]$. Sustainable crop productivity is largely dependent on the physicochemical and biological properties of soil and also related to some extent of biodiversity [10-12]. The CA practice enhances soil quality and improves soil health besides reducing the cultivation cost [13]. Moreover, the performance of some crops like wheat (Triticum aestivum L.), lentil (Lens culinaris (L.)), rainy season rice (Oryza sativa L.) and maize (Zea mays L.) were found to grow better under the CA system in Bangladesh as compared to the conventional system [14-17].

However, the infestation of weeds is considered a major hindrance in the transformation of a conventionally tilled field to the CA-based field. Because, in the conventional system, heavy tillage offers benefits in suppressing weeds by incorporation under the soil $[18,19]$. However, this consequence has a great influence on the enrichment of weed seed bank [20], because of the deposition of weed seeds at different layers of soils. Weed infestation remains high under the CA-based cultivation system in the initial few years due to the absence of the pulverization of soil or limited tillage. That is why weed seeds of the CA field mostly remain on the sub-surface layer of soil and are germinated in favorable conditions. Later on, the rate of weeds infestation declines in the CA system over time due to very limited weeds seeds staying behind in the sub-surface layer of soil to germinate and the CA practice ensures no chance for further weeds seeds to emerge from the deep soil. Therefore, it is established that in the CA system, weed management plays a vital role to obtain an attainable yield [21-23]. This system highly relies on using herbicides for weed control. The cost and unavailability of labor are now forcing farmers to shift from manual weeding to the application of herbicides for controlling weeds [24,25].

In Bangladesh, farmers are not well aware of the proper use of herbicides. They apply the same chemical compound in the same field for years that may influence the development of herbicide-resistant weeds quickly [26]. Therefore, the selection of suitable herbicides for the crops in a cropping pattern is very important to avoid the risk of rapid herbicide-resistant weeds in the intensive cropping systems of Bangladesh. Moreover, in our country's market, most available herbicides are intended for rice and very few for the other crops. On the other hand, most of the registered herbicides are not out of the market and not available in all sites of the country. Therefore, farmers often face a problem obtaining appropriate herbicides for managing weeds effectively in crops including rice. Therefore, it is important to find out a list of suitable pre-and post-emergence herbicides for the farmers to apply sequentially in a whole crop growing period for effective weed control.

Crop rotation can also play a significant role in weed management [27] by shifting the time of emergence of weed flora. Several research reports revealed that small grain crops require less weed control than large grain crops like maize or soybean [28-31]. A wellmanaged weed-controlled crop field is very important to achieve target yield. A popular age-old cropping system like the rice-wheat $(\mathrm{R}-\mathrm{W})$ system can also suffer significant yield loss because of poor weed management [32]. The inclusion of a legume crop within the R-W system is beneficial for the nation to achieve food and nutrition security. Rice-wheat-mung bean is one of the profitable cereal-legume-based patterns that is particularly practiced in 
the northern and southern part of the country [33,34]. Cynodon dactylon (L.) is a commonly available weed for both rice and wheat fields. In rice, grass weeds have dominancy over the crop if they remain uncontrolled, whereas broadleaf weeds have dominance in wheat crop and cause significant yield loss $[21,35,36]$. There are few common weeds in rice and wheat under the intensive rice-wheat cropping system and their management is often a challenge for farmers. Therefore, for managing weeds of rice and wheat under a CA-based wheat-mung bean-rice cropping system, this study was designed to select effective and economic herbicides for ensuring the maximum desirable yield and economic benefit.

\section{Materials and Methods}

\subsection{Area of the Study}

The experiment was initiated with strip-planted wheat in winter of 2017-2018 and completed with non-puddled rainy season rice in 2019. Two years of a cropping cycle has been completed in the on-station field of the on-farm research division, Bangladesh Agricultural Research Institute (BARI), Joydebpur, Gazipur, Bangladesh $\left(23^{\circ} 59^{\prime} 8.83999^{\prime \prime} \mathrm{N}\right.$ and $90^{\circ} 24^{\prime} 37.58999^{\prime \prime} \mathrm{E}$ ). The study was carried out in medium-high land in sandy loam textured soil with very low organic matter (OM) (Table 1). Collection of the initial soil sample was from the experimental ground at $0-20 \mathrm{~cm}$ depth before growing the first wheat crop and analyzed in the laboratory of Soil Science Division, Bangladesh Agricultural Research Institute, Bangladesh. The status of the initial soil has been given in Table 1.

Table 1. Chemical and physical properties of initial soil at the experimental field.

\begin{tabular}{|c|c|c|c|c|c|c|c|c|c|}
\hline Properties & $\mathrm{pH}$ & OM (\%) & $\begin{array}{c}\text { Total N } \\
(\%)\end{array}$ & $\begin{array}{c}\text { P ( } \mu \mathrm{g} / \mathrm{g} \\
\text { Soil) }\end{array}$ & $\begin{array}{c}\mathrm{K} \text { (meq./100 g } \\
\text { Soil) }\end{array}$ & $\begin{array}{c}\text { S ( } \mu \mathrm{g} / \mathrm{g} \\
\text { Soil) }\end{array}$ & $\begin{array}{c}\mathrm{Zn}(\mu \mathrm{g} / \mathrm{g} \\
\text { Soil) }\end{array}$ & $\begin{array}{c}\text { B ( } \mu \mathrm{g} / \mathrm{g} \\
\text { Soil) }\end{array}$ & $\begin{array}{c}\text { Soil } \\
\text { Texture }\end{array}$ \\
\hline Value & 5.04 & 0.87 & 0.053 & 12.69 & 0.227 & 15.00 & 0.788 & 0.213 & \multirow{2}{*}{$\begin{array}{c}\text { Sandy } \\
\text { loam }\end{array}$} \\
\hline Interpretation & Acidic & Low & VL & M & Opt & M & M & $\mathrm{L}$ & \\
\hline
\end{tabular}

Here, OM = Organic matter, N = Nitrogen; P = Phosphorus; K = Potassium; S = Sulphur; Zn = Zinc; B = Boron; VL = very low, $\mathrm{L}=$ low, $\mathrm{M}=$ medium, $\mathrm{Opt}=$ optimum. (Classified as per Fertilizer Recommendation Guide-2018) [37].

\subsection{Climatic Condition during Cropping Seasons}

Data of the maximum and minimum air temperature of the experimental period is shown in Figure 1 on a monthly basis, along with the monthly total rainfall data in Figure 2 (Source: Weather station, Bangladesh Meteorological Department, Joydebpur, Gazipur, Bangladesh).

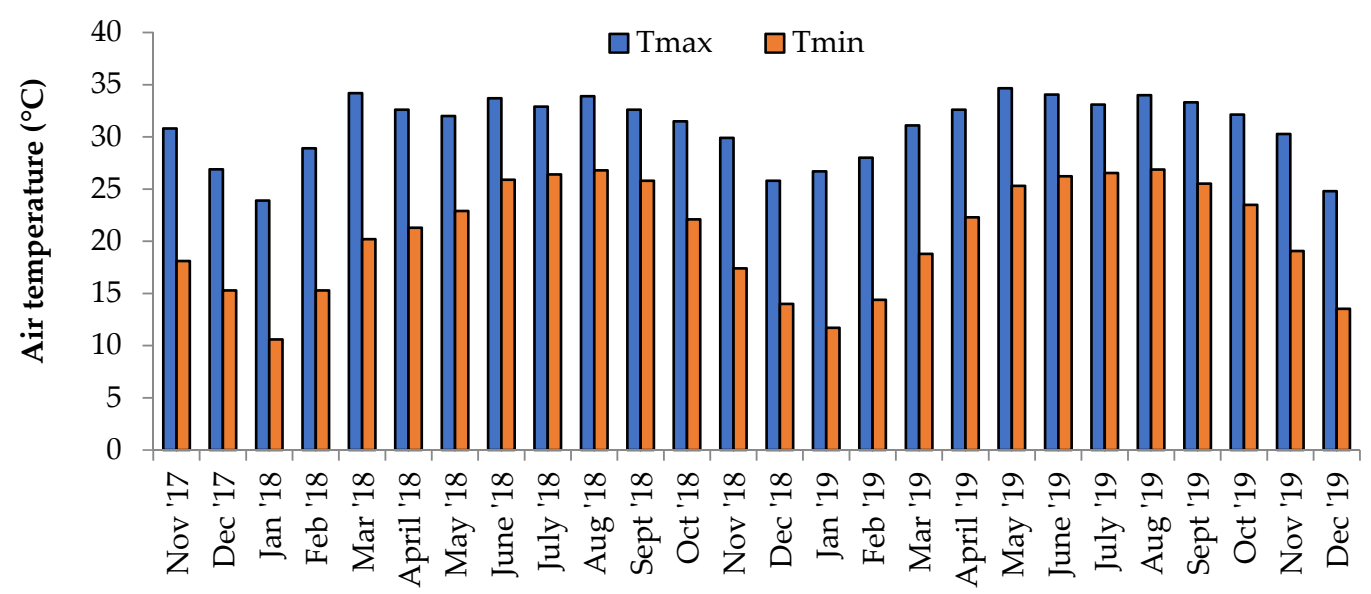

Figure 1. Monthly average of maximum (Tmax) and minimum (Tmin) air temperature at the experimental site from November 2017 to December 2019.

In the first year of the study, the wheat crop experienced a monthly average of the maximum temperature ranging from 23.9 to $34.2^{\circ} \mathrm{C}$ and a minimum temperature ranging 
from 10.6 to $20.2{ }^{\circ} \mathrm{C}$ (Figure 1). In the next year, the monthly average maximum and minimum temperatures ranged from 25.8 to $31.1^{\circ} \mathrm{C}$ and 11.7 to $18.8^{\circ} \mathrm{C}$, respectively.

In the first wheat season (November 2017 to March 2018) $96 \mathrm{~mm}$ of rainfall occurred, while in the second wheat season (November 2018 to March 2019) the rainfall was $178 \mathrm{~mm}$ (Figure 2). Rainy season rice was transplanted during July and harvested in November. The monthly average maximum air temperatures were recorded in August $2018\left(33.9^{\circ} \mathrm{C}\right)$ and May $2019\left(34.7^{\circ} \mathrm{C}\right)$. The lowest monthly average minimum temperature was in January for both years $\left(10.6^{\circ} \mathrm{C}\right.$ in 2018 and $11.7^{\circ} \mathrm{C}$ in 2019). During 2018, the maximum rainfall was recorded in May and then in April. In the next year, the experimental field received the maximum rainfall in July.

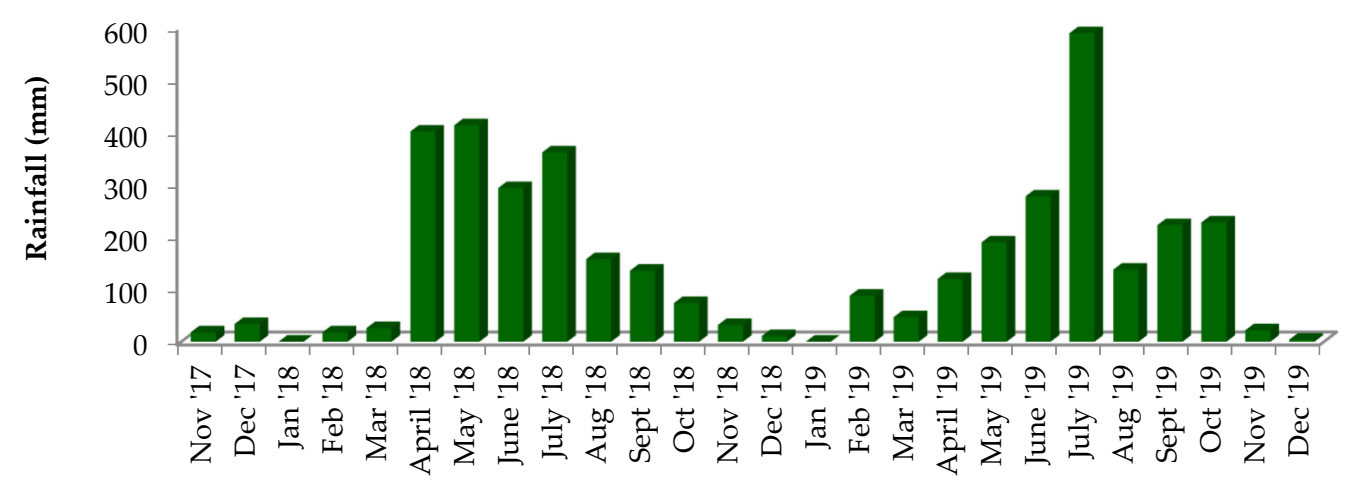

Figure 2. Month wise total rain at the experimental site from November 2017 to December 2019.

\subsection{Experimental Treatments and Design}

In wheat, the performance of two herbicides (Pendimethalin as preemergence and carfentrazone-ethyl + isoproturon as postemergence) was evaluated by comparing with the 'weedy' and 'weed free' treatments as a check to observe the efficacy and economic of herbicide(s). The study considered five treatments such as $\mathrm{T}_{1}=$ weedy check (no weed control), $\mathrm{T}_{2}=$ weed free check (manually weeded twice at 30 and $45 \mathrm{DAS}$ ), $\mathrm{T}_{3}=$ Pendimethalin (as pre-emergence), $\mathrm{T}_{4}=$ Pendimethalin (as pre-emergence) followed by (fb) carfentrazoneethyl + isoproturon (as post-emergence) and $\mathrm{T}_{5}=$ carfentrazone-ethyl + isoproturon (as post-emergence). The wheat trial was conducted in a randomized complete block (RCB) design and replicated three times. The net plot area of the wheat trial was $4 \mathrm{~m}$ in length and $3 \mathrm{~m}$ in width. No herbicide was provided in mung bean as treatment nor as a weed controlling means.

For non-puddled rainy season rice, the efficacy of three herbicides (two pre-emergence herbicides namely pretilachlor and pyrazosulfuron-ethyl; one post-emergence herbicide namely bispyribac-sodium) rice was evaluated, where for comparing the 'weedy' and 'weed free', treatments were considered as check. Therefore, treatments were: $\mathrm{T}_{1}=$ weedy check, $\mathrm{T}_{2}=$ weed-free check (manually weeded three times at 25, 35 and 45 days after transplanting $(\mathrm{DAT})), \mathrm{T}_{3}=$ pretilachlor (pre-emergence), $\mathrm{T}_{4}=$ pyrazosulfuron-ethyl (preemergence), $\mathrm{T}_{5}=$ pretilachlor (pre-emergence) fb bispyribac-sodium (post-emergence) and $\mathrm{T}_{6}=$ pyrazosulfuron-ethyl (pre-emergence) fb bispyribac-sodium (post-emergence). The rice experiment was also laid out in the same experimental field following RCB design with three replications just after breaking the 'ailes' (boundaries) of the previous plots with the help of a ladder. The unit plot size for the rice experiment was $3 \mathrm{~m} \times 3 \mathrm{~m}$.

\subsection{Experimental Procedure}

Before initiation of the experiment, the wheat field already had $20 \mathrm{~cm}$ standing residue from the previous rainy season rice crop. However, prior to planting wheat, no herbicide was applied as the field was free from weeds. Wheat was seeded within the strips apart by $20 \mathrm{~cm}$ at the rate of $150 \mathrm{~kg} \mathrm{ha}^{-1}$ by a strip planter. Before strip-till, fertilizers, such as phosphorus, potassium and sulfur, were applied at 60,25 and $18 \mathrm{~kg} \mathrm{ha}^{-1}$, respectively, 
in the form of triple superphosphate (TSP), muriate of potash (MoP) and gypsum. All fertilizers were applied immediately before seeding of wheat. Nitrogen was applied in the form of urea at $200 \mathrm{~kg} \mathrm{ha}^{-1}$ in two equal instalments. The first instalment was applied at 15 days after sowing (DAS) and the second one was at the panicle initiation stage (PI). Pendimethalin (pre-emergence herbicide) was applied at 02 DAS and carfentrazone-ethyl + isoproturon (applied as a post-emergence herbicide) was applied at 25 DAS by using a hand-operated knapsack sprayer (plastic-bodied) with a flat-fan nozzle. The spray volume was $300 \mathrm{~L} \mathrm{ha}^{-1}$ and the delivery pressure was $0.3 \mathrm{MPa}$. The details of the tested herbicides are provided in Table 2.

Table 2. The chemical and commercial name and rate of application along with the manufacturers of the tested herbicides.

\begin{tabular}{|c|c|c|c|c|c|}
\hline \multirow{2}{*}{ Crops } & \multicolumn{4}{|c|}{ Herbicides } & \multirow{2}{*}{ Equipment } \\
\hline & Chemical Name & Commercial Name & Rate of Application & Manufacturers & \\
\hline \multirow[t]{2}{*}{ Wheat } & Pendimethalin & Panida33EC & $1.0 \mathrm{~kg} \mathrm{ha}^{-1}$ & $\begin{array}{l}\text { Auto crop care Ltd., } \\
\text { Dhaka, Bangladesh }\end{array}$ & \multirow{5}{*}{$\begin{array}{c}\text { A hand-operated } \\
\text { knapsack sprayer } \\
\text { (plastic-bodied) with } \\
\text { a flat-fan nozzle was } \\
\text { used for spraying the } \\
\text { herbicide }\end{array}$} \\
\hline & $\begin{array}{c}\text { Carfentrazone-ethyl + } \\
\text { Isoproturon }\end{array}$ & Affinity $50.75 \mathrm{WP}$ & $25.51 \mathrm{~kg} \mathrm{ha}^{-1}$ & $\begin{array}{l}\text { Auto crop care Ltd., } \\
\text { Dhaka, Bangladesh }\end{array}$ & \\
\hline \multirow{3}{*}{$\begin{array}{l}\text { Rainy } \\
\text { season rice }\end{array}$} & Pretilachlor & Commit 500EC & $0.5 \mathrm{~kg} \mathrm{ha}^{-1}$ & $\begin{array}{l}\text { Auto crop care Ltd., } \\
\text { Dhaka, Bangladesh }\end{array}$ & \\
\hline & Pyrazosulfuron-ethyl & Manage 10WP & $1.5 \mathrm{~g} \mathrm{ha}^{-1}$ & $\begin{array}{l}\text { MacDonald Ltd., } \\
\text { Dhaka, Bangladesh }\end{array}$ & \\
\hline & Bispyribac-sodium & Prune 20WP & $150 \mathrm{~g} \mathrm{ha}^{-1}$ & $\begin{array}{l}\text { Auto crop care Ltd., } \\
\text { Dhaka, Bangladesh }\end{array}$ & \\
\hline
\end{tabular}

Here, 'BD' stands for 'Bangladesh'.

The wheat crop was irrigated four times to obtain better germination, stand establishment of seedling vigor and growth since a very small amount of rainfall occurred during the wheat-growing period (Figure 2). Wheat was harvested at full maturity and then mung bean seeds were sown in the same field with a seed rate of $35 \mathrm{~kg} \mathrm{ha}^{-1}$ with the strips apart by $20 \mathrm{~cm}$. However, the crop was completely damaged by the stagnation of water due to continuous rainfall for a few weeks.

In case of rainy season rice, 25 days old rice seedlings were manually planted in a strip-tilled field at $15 \mathrm{~cm} \times 20 \mathrm{~cm}$ spacing with 3 seedlings per hill. Before transplanting the rice seedlings, chemical fertilizers such as phosphorus, potassium, sulfur and zinc at the rate of 24, 35, 10 and $3.5 \mathrm{~kg} \mathrm{ha}^{-1}$ as a form of TSP, MoP, Gypsum and $\mathrm{ZnSO}_{4}$, respectively. A dose of $70 \mathrm{~kg} \mathrm{~N}^{-1}$ was applied as urea in two splits: at 10 and 35 DAT. The strips set apart by $20 \mathrm{~cm}$ were made by a hand tine and then $3-5 \mathrm{~cm}$ of water stagnation was maintained for $48 \mathrm{~h}$.

In the case of two pre-emergence herbicides namely pretilachlor and pyrazosulfuronethyl, which were applied at 3 DAT and post-emergence herbicide namely bispyribacsodium was applied at 20 DAT. Rainy season rice was reaped at maturity retaining $20 \mathrm{~cm}$ crop residue and then again strip planted wheat and then mung bean was sown to complete the cycle of wheat-mung bean-rice cropping pattern. The dates of planting and harvesting along with the name of the used varieties were mentioned in Table 3.

Table 3. Variety, date of planting and date of harvest of wheat, mung bean and rainy season rice between 2017-2019 at Gazipur, Bangladesh.

\begin{tabular}{|c|c|c|c|}
\hline Crops & Variety & Date of Planting & Date of Harvest \\
\hline \multirow{2}{*}{ Wheat } & \multirow{2}{*}{ BARI Gom 30} & 29 November 2017 & 20 March 2018 \\
\hline & & 17 November 2018 & 26 March 2019 \\
\hline \multirow{2}{*}{ Mung bean } & \multirow{2}{*}{ BARI mung 6} & 28 March 2018 & Damaged due to heavy rainfall \\
\hline & & 7 April 2019 & (Figure 2) \\
\hline \multirow{2}{*}{ Rainy season rice } & \multirow{2}{*}{ BRRI dhan71 } & 08 July 2018 & 21 October 2018 \\
\hline & & 29 July 2019 & 12 November 2019 \\
\hline
\end{tabular}




\subsection{Data and Their Collection Procedures}

Data on weed density and biomass were gathered from two randomly selected spots by using a $50 \mathrm{~cm} \times 50 \mathrm{~cm}$ quadrat for both wheat and rice crops. Identification of weed species was done and species-wise weed density was counted by uprooting the whole plant and then converted into an area of $1 \mathrm{~m}^{2}$. In case of weed biomass, the whole weed plants were cleaned with fresh tap-water, air-dried and then fresh weight was taken for each species. Species-wise dry weed biomass was measured after drying the samples in an electric oven for $72 \mathrm{~h}$ maintaining a constant temperature of $80^{\circ} \mathrm{C}$ and expressed in $\mathrm{g} \mathrm{m}^{-2}$. Data on yield attributes were recorded from ten randomly selected plants of each plot. Crop yields were noted from the $2 \mathrm{~m} \times 3 \mathrm{~m}$ area of each plot in the middle portion and dry biomass was converted into tha ${ }^{-1}$.

\subsection{Statistical Analysis}

The recorded data were analyzed statistically by computing the platform of ' $R$ ', version 3.3.3 [38]. Before analyzing the data statistically, the goodness of fit of all recorded data was measured through descriptive statistics. To determine if a data set is well-modelled by a normal distribution and to compute how likely it is for a random variable underlying the data set to be normally distributed, a normality test was done. Analysis of variance (ANOVA) was carried out to examine the effects of pre- and post-emergence herbicides on weed density, weed biomass and also on yield and yield contributing characters of wheat and rice under wheat-mung bean-rice cropping system. For weed data, 'weedy check' was considered as a control treatment and analyzed for comparison with the other treatments except 'weed free' as a check treatment. Similarly, for yield and yield attributes, 'weed free' was considered as a control treatment and statistically compared with other treatments along with 'weedy check'. The comparison on treatment means was done using the Least Significant Difference (LSD) test at $p \leq 0.05$.

\subsection{Economic Analysis}

Economic analysis was done to evaluate the cost involvement (fixed costs and variable costs as well) and benefits of herbicide treatments as described in the procedure by Parvez et al. [39]. Manual weeding twice was considered for 'weed free' treatment in wheat and three times manual weeding for rice. The required number of laborers for manual weed management and one round herbicide spray hectare ${ }^{-1}$ of land was 25 and 1, respectively. The wage of one laborer was estimated as USD 4.17 per day. The cost of herbicides was calculated based on the existing local market price. The price of grain and straw of wheat and rice was calculated as per the price fixed by the Bangladesh government. The treatment wise net benefit hectare ${ }^{-1}$ was computed by subtracting the total cost (fixed cost + variable cost) from the gross return.

\section{Results and Discussion}

\subsection{Effect of Herbicides on Weeds in Strip-Till Wheat}

In wheat, there were eight weed species in the winter of 2017-2018; of these three were grasses (Cynodon dactylon (L.) Pers., Digitaria sanguinalis (L.) Scop. and Echinochloa colonum (L.) Link) and five were broadleaved weeds (Polygonum hydropiper L., Physalis heterophylla (L.) Nees, Chenopodium album (L.), Eclipta prostrata (L.) and Portulaca oleracea (L.)). During 2018-2019, fourteen weed types were observed of which five were grasses (Cynodon dactylon (L.), Digitaria sanguinalis (L.), Echinochloa colonum (L.), Echinochloa crus-galli (L.) (Beauv) and Oryza rufipogon Griff.), one was sedge (Cyperus rotundus (L.)) and eight were broadleaved weeds (Enhydra fluctuans Lour, Physalis heterophylla (L.), Alternanthera sessilis (L.) R.Br. ex DC., Pseudognaphalium affine (D. Don) Anderb, Brassica kaber (L.), Lindernia procumbens (Krock.) Philcox, Vicia sativa (L.) and Amaranthus viridis (L.)) (Table 4). 
Table 4. Weed species in weedy check plots of strip-planted wheat at 35 DAS in both years (2017-2018 and 2018-2019).

\begin{tabular}{|c|c|c|c|c|c|c|}
\hline \multirow[t]{2}{*}{ Weed Species } & \multirow[t]{2}{*}{ English Name } & \multirow[t]{2}{*}{ EPPO Code } & \multirow[t]{2}{*}{ Family } & \multirow[t]{2}{*}{ Life Cycle } & \multicolumn{2}{|c|}{$\begin{array}{c}\% \text { Weed Infestation (Based on } \\
\text { Weed Density) }\end{array}$} \\
\hline & & & & & $2017-2018$ & 2018-2019 \\
\hline & \multicolumn{6}{|c|}{ Grass } \\
\hline Cynodon dactylon & Bermuda grass & CYNDA & Poaceae & Perennial & 16.5 & 12.9 \\
\hline Digitaria sanguinalis & Crab grass & DIGSA & Poaceae & Annual & 3.9 & 30.9 \\
\hline Echinochloa colonum & Jungle rice & $\mathrm{ECHCO}$ & Poaceae & Annual & 7.5 & 14.3 \\
\hline Echinochloa crus-galli & Barnyard grass & ECHCG & Poaceae & Annual & - & 11.2 \\
\hline \multirow[t]{2}{*}{ Oryza rufipogon } & Wild rice & ORYRU & Poaceae & Annual & - & 5.7 \\
\hline & \multicolumn{6}{|c|}{ Sedge } \\
\hline \multirow[t]{2}{*}{ Cyperus rotundus } & Nutsedge & CYPRO & Cyperaceae & Perennial & - & 1.8 \\
\hline & \multicolumn{6}{|c|}{ Broadleaf } \\
\hline Polygonum hydropiper & Marsh pepper & POLHY & Polygonaceae & Perennial & 2 & - \\
\hline Vicia sativa & Wild lentil/vetch & VICSA & Fabaceae & Perennial & - & 1.8 \\
\hline Physalis heterophylla & $\begin{array}{l}\text { Clammy ground } \\
\text { cherry }\end{array}$ & PHYHE & Solanaceae & Perennial & 63.9 & 0.9 \\
\hline Portulaca oleracea & $\begin{array}{l}\text { Common } \\
\text { purslane/duckweed }\end{array}$ & POROL & Portulacaceae & Perennial & 1.3 & - \\
\hline Eclipta prostrata & False daisy & ECLAL & Asteraceae & Perennial & 3.3 & - \\
\hline Chenopodium album & Lamb's quarters & CHEAL & Amaranthaceae & Perennial & 1.6 & - \\
\hline Pseudognaphalium affine & Cud weed & GNAAF & Asteraceae & Perennial & - & 1.4 \\
\hline Enhydra fluctuans & Water spinach & - & Asteraceae & Perennial & - & 15.0 \\
\hline Amaranthus viridis & Slender amaranth & AMAVI & Amaranthaceae & Perennial & - & 0.9 \\
\hline Alternanthera sessilis & Dwarf copper leaf & ALRSE & Amaranthaceae & Perennial & - & 1.8 \\
\hline Brassica kaber & $\begin{array}{l}\text { Wild mus- } \\
\text { tard / }\end{array}$ & SINAR & Brassicaceae & Perennial & - & 0.9 \\
\hline Lindernia procumbens & Lindernia & LIDPY & Linderniaceae & Annual & - & 0.5 \\
\hline
\end{tabular}

The increasing number of weed species in the second year of the study might be related to having more dry soil and weather than the first year (Figure 2). There is evidence that indicates a water-limited dry environment may promote weed seed germination while germination may be delayed in wetter conditions [40-42]. Moreover, the presence of crop residue on the soil surface in the drier site or year was found less effective for the suppression of weed species [43-45]. Thus, it can be assumed that the effectiveness of herbicide in the second year of study was absent or lower than in the first year due to lack of soil moisture, resulting in greater weed infestation in the second year. Moreover, the crop-weed competition under water stress conditions is highly dependent on the survival ability and physiological mechanisms of both crop-weed species [46]. Chadha et al. [47] notified a severe threat from some weeds that have a better adaptive mechanism during drought stress than crops under a scarcity of rainfall during the dry season. The study marked out that PHYHE (63.9\%) was the most dominant weed species in 2017-2018 and DIGSA (30.9\%) was in 2018-2019 (Table 4). The high weed seeds shedding of these species in the weed seed bank in the previous year might be responsible for creating more weeds in the next year [48].

Herbicide treatments had a significant effect on the densities of grass weeds $(p \leq 0.001)$ and broadleaf weeds ( $p \leq 0.01$ in 2017-2018 and $p=$ ns (non-significant) in 2018-2019). The highest densities of grass weed ( 289 plants $\mathrm{m}^{-2}$ in 2017-2018 and 216 plants $\mathrm{m}^{-2}$ in 20182019), sedge (5 plants $\mathrm{m}^{-2}$ in 2018-2019) and broadleaf weed (745 plants $\mathrm{m}^{-2}$ in 2017-2018 and 67 plants $\mathrm{m}^{-2}$ in 2018-2019) were recorded from the 'weedy check' plots. The study demonstrated that all herbicides reduced the density of grasses by $6-71 \%$ and broadleaf by 72-95\%, as compared to the 'weedy check' during 2017-2018 (Figure 3). During 2018-2019, herbicides also reduced grasses by $39-75 \%$, sedges by $100 \%$ and broadleaf weeds by $39-77 \%$ (Figure 4). Zahan et al. [21] also reported that all types of weeds in strip-planted wheat were effectively controlled by the application of herbicides. 


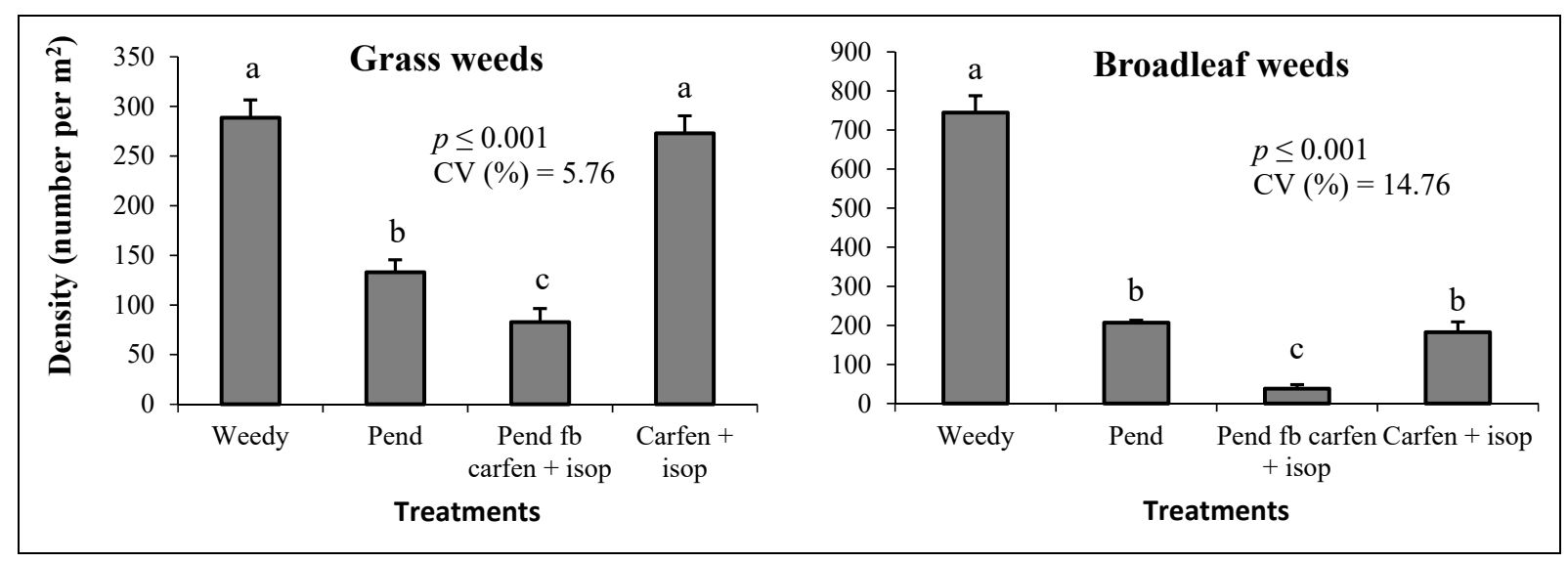

Figure 3. Impact of herbicides on the density of grass and broadleaf weeds at 35 DAS in strip-planted wheat during 2017-2018 season. Here, 'Pend' stands for 'pendimethalin'; 'carfen + isop' stands for 'carfentrazone-ethyl + isoproturon'; 'CV' stands for 'coefficient of variation'. Different small letters indicate statistically significant differences.

All types of weeds were reduced significantly when the herbicide pendimethalin was applied as pre-emergence treatment followed by carfentrazone-ethyl + isoproturon as postemergence treatment in both years (Figures 3 and 4). Sole application of pendimethalin as pre-emergence provided the lowest reductions of broadleaf weeds in both years. In case of grasses, the controlling efficacy of carfentrazone-ethyl + isoproturon (post-emergence) was poor in the first season and pendimethalin (pre-emergence) was in the next season. These results indicate that sole application of herbicide is not sufficient to control various types of weeds, while several earlier reports confirmed that sequentially applied pre-and post-emergence herbicides can effectively control weeds [24,47-50].

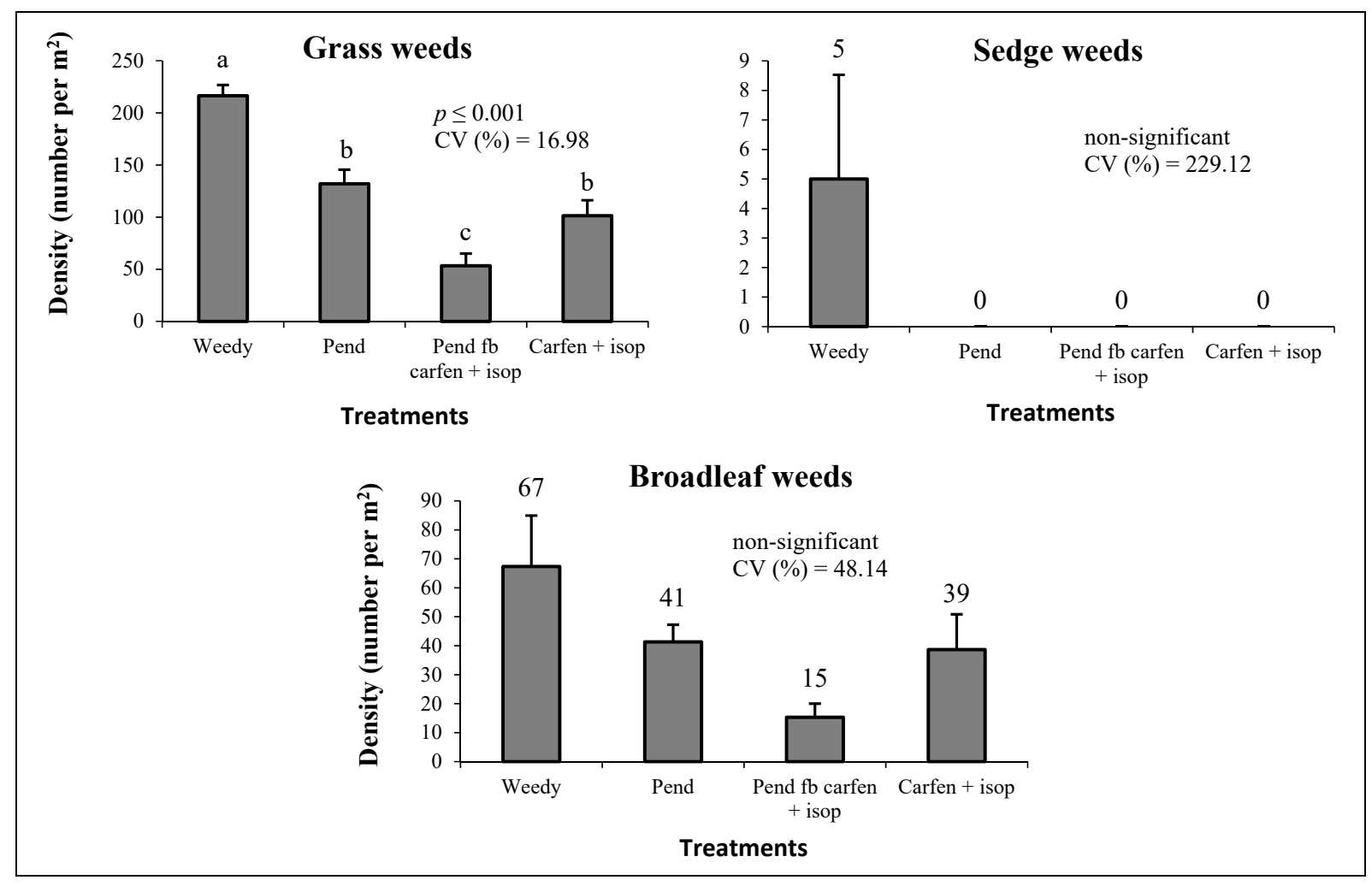

Figure 4. Impact of herbicides on the density of grass, sedge and broadleaf weeds at 35 DAS in strip-planted wheat during 2018-2019 season. Here, 'Pend' stands for 'pendimethalin'; 'carfen + isop' stands for 'carfentrazone-ethyl + isoproturon'. Different small letters indicate statistically significant differences. 
The weedy check plots had the highest weed density and biomass during both years (Table 5). However, all herbicides offered a significant reduction in total weed density and biomass as compared to the weedy check. Pre-emergence application of pendimethalin followed by carfentrazone-ethyl + isoproturon applied as post-emergence presented the maximum reduction in weed density $(88 \%$ and $76 \%)$ and biomass $(78 \%$ and $71 \%)$ in both seasons.

Table 5. Effect of herbicides on total weed density and biomass at 35 days after sowing of wheat under conservation agricultural systems in both years (2017-2018 and 2018-2019).

\begin{tabular}{|c|c|c|c|c|}
\hline \multirow{2}{*}{ Treatments } & \multicolumn{2}{|c|}{ Total Weed Density (no. $\mathrm{m}^{-2}$ ) } & \multicolumn{2}{|c|}{ Total Dry Biomass $\left(\mathrm{g} \mathrm{m}^{-2}\right)$} \\
\hline & 2017-2018 & 2018-2019 & 2017-2018 & 2018-2019 \\
\hline Weedy check & $1033.3 \mathrm{a}$ & $289.0 \mathrm{a}$ & $95.72 \mathrm{a}$ & $76.80 \mathrm{a}$ \\
\hline Pendimethalin & $340.0 \mathrm{c}$ & $173.3 \mathrm{~b}$ & $20.07 \mathrm{~b}$ & $44.80 \mathrm{~b}$ \\
\hline $\begin{array}{c}\text { Pendimethalin } \mathrm{fb} \\
\text { Carfentra + isopoturon }\end{array}$ & $120.7 \mathrm{~d}$ & $68.7 \mathrm{c}$ & $7.77 \mathrm{~d}$ & $22.53 \mathrm{~b}$ \\
\hline Carfentra + isoproturon & $455.3 \mathrm{~b}$ & $140.0 \mathrm{~b}$ & $12.59 \mathrm{c}$ & $30.67 \mathrm{~b}$ \\
\hline F-Test & $* * *$ & $* * *$ & $* * *$ & ** \\
\hline CV $(\%)$ & 8.66 & 17.52 & 7.07 & 27.35 \\
\hline
\end{tabular}

In a column, means with similar letter(s) are identical as per $\mathrm{LSD}_{0.05} ; \mathrm{fb}=$ followed by, Carfen $=$ carfentrazone-ethyl, $\mathrm{CV}=\mathrm{co}$-efficient of variance, $^{* * *}=0.1 \%$ level of significance, ${ }^{* *}=1 \%$ level of significance.

\subsection{Impact of Herbicides on Yield Attributes and Yield of Wheat and Economic Analysis}

All herbicides used for controlling weeds significantly affected the yield and yield attributes of wheat, except spike length in both years (Table 6), and grains spike ${ }^{-1}$ in the second season (Table 7). The maximum grain and straw yields were noted with pendimethalin (as pre-emergence) followed by carfentrazone-ethyl + isoproturon (as postemergence) as the sequential application of these herbicides also produced the maximum tillers and heads. This might happen because pendimethalin as pre-emergence followed by carfentrazone-ethyl + isoproturon applied as post-emergence offered the most effective weed controls that helped the crop to produce the highest number of tillers and heads. The inferior number of tillers, heads, grains spike ${ }^{-1}$, grain and straw yields were recorded in the 'weedy check' plot.

Table 6. Impact of herbicides on yield and yield attributes of strip-planted wheat in the first season (2017-2018).

\begin{tabular}{|c|c|c|c|c|c|c|}
\hline Treatments & $\begin{array}{c}\text { Tillers } \\
\text { (no. } \mathrm{m}^{-2} \text { ) }\end{array}$ & $\begin{array}{c}\text { Heads } \\
\left(\text { no. } m^{-2}\right)\end{array}$ & $\begin{array}{l}\text { Spike Length } \\
\text { (cm) }\end{array}$ & $\begin{array}{c}\text { Grains } \\
\text { Spike }^{-1} \\
\text { (no.) }\end{array}$ & $\begin{array}{l}\text { Grain Yield } \\
\quad\left(\mathrm{t} \mathrm{ha}^{-1}\right)\end{array}$ & $\begin{array}{l}\text { Straw Yield a } \\
\quad\left(\mathrm{t} \mathrm{ha}^{-1}\right)\end{array}$ \\
\hline Weedy check & $136 \mathrm{~d}$ & $132 \mathrm{~d}$ & 16.67 & $31 \mathrm{c}$ & $0.92 \mathrm{~d}$ & $1.89 \mathrm{c}$ \\
\hline Weed-free check & $345 \mathrm{~b}$ & $342 \mathrm{~b}$ & 17.20 & $38 \mathrm{~b}$ & $4.00 \mathrm{a}$ & $5.94 \mathrm{ab}$ \\
\hline Pendimethalin & $320 c$ & $315 c$ & 16.87 & $40 \mathrm{ab}$ & $3.01 \mathrm{c}$ & $5.55 \mathrm{~b}$ \\
\hline $\begin{array}{l}\text { Pendimethalin } \mathrm{fb} \\
\text { Carfen }+ \text { isop }\end{array}$ & $416 \mathrm{a}$ & $413 \mathrm{a}$ & 17.27 & $42 \mathrm{a}$ & $4.20 \mathrm{a}$ & $6.36 \mathrm{a}$ \\
\hline Carfen + isop & $343 \mathrm{bc}$ & $339 \mathrm{~b}$ & 16.97 & $36 \mathrm{~b}$ & $3.62 \mathrm{~b}$ & $6.01 \mathrm{ab}$ \\
\hline F-Test & $* * *$ & $* * *$ & $\mathrm{~ns}$ & $* *$ & $* * *$ & $* * *$ \\
\hline CV $(\%)$ & 4.25 & 3.75 & 5.96 & 5.15 & 6.09 & 3.33 \\
\hline
\end{tabular}

In the column, means with the similar letter(s) are statistically identical as per $\mathrm{LSD}_{0.05}$; Here, carfen + isop = carfentrazone-ethyl + isoproturon, $\mathrm{CV}=$ co-efficient of variance, ${ }^{* * *}=0.1 \%$ level of significance, ${ }^{* *}=1 \%$ level of significance, $\mathrm{ns}=$ non-significant; ${ }^{\text {a }}$ Straw yield was estimated on sun dry basis. 
Table 7. Impact of herbicides on yield and yield attributes of strip-planted wheat in the second season (2018-2019).

\begin{tabular}{|c|c|c|c|c|c|c|}
\hline Treatments & $\begin{array}{c}\text { Tillers } \\
\left.\text { (no. } \mathrm{m}^{-2}\right)\end{array}$ & $\begin{array}{c}\text { Heads } \\
\left(\text { no. } \mathrm{m}^{-2}\right)\end{array}$ & $\begin{array}{l}\text { Spike Length } \\
\text { (cm) }\end{array}$ & $\begin{array}{l}\text { Grains } \\
\text { Spike }^{-1} \\
\text { (no.) }\end{array}$ & $\begin{array}{l}\text { Grain Yield } \\
\quad\left(\mathrm{t} \mathrm{ha}^{-1}\right)\end{array}$ & $\begin{array}{l}\text { Straw Yield }{ }^{a} \\
\quad\left(\mathrm{t} \mathrm{ha}^{-1}\right)\end{array}$ \\
\hline Weedy check & $251 \mathrm{c}$ & $246 c$ & 17.0 & 43.9 & $2.29 \mathrm{c}$ & $3.60 \mathrm{c}$ \\
\hline Weed-free check & $343 \mathrm{a}$ & $339 \mathrm{ab}$ & 17.2 & 41.3 & $3.53 \mathrm{~b}$ & $4.73 \mathrm{~b}$ \\
\hline Pendimethalin & 337 a & $332 \mathrm{ab}$ & 17.4 & 45.1 & $3.27 \mathrm{~b}$ & $4.53 \mathrm{~b}$ \\
\hline \multicolumn{7}{|l|}{ Pendimethalin $\mathrm{fb}$} \\
\hline $\begin{array}{l}\text { Carfentra + } \\
\text { isoproturon }\end{array}$ & 357 a & 350 a & 17.5 & 46.6 & $4.27 \mathrm{a}$ & $5.20 \mathrm{a}$ \\
\hline $\begin{array}{l}\text { Carfentra + } \\
\text { isoproturon }\end{array}$ & $303 \mathrm{~b}$ & $299 \mathrm{~b}$ & 17.3 & 45.7 & $3.73 \mathrm{ab}$ & $4.70 \mathrm{~b}$ \\
\hline F-Test & $* * *$ & $* *$ & ns & ns & $* *$ & $* * *$ \\
\hline CV $(\%)$ & 5.56 & 6.78 & 2.30 & 4.77 & 10.35 & 4.92 \\
\hline
\end{tabular}

Abbreviations as mentioned in the previous table (Table 5); Carfentra + isoproturon = carfentrazone-ethyl + isoproturon; ns, non-significant; $* * *, 0.1 \%$ level of significance; ${ }^{* *}$, significant at $1 \%$ level; ${ }^{\text {a }}$ Straw yield was estimated on sundry basis.

The economic analysis results expressed that herbicidal weed control is more profitable than manual weed control (Table 8). Two years of economic results showed that application of pendimethalin fb carfentrazone-ethyl + isoproturon was more profitable by $26-63 \%$ than the weed-free check; this is due to the high-cost involvement for labor in manual weeding.

Table 8. Economic performance of herbicides in wheat in both years.

\begin{tabular}{|c|c|c|c|c|c|c|}
\hline \multirow{2}{*}{ Treatments } & \multicolumn{2}{|c|}{$\begin{array}{l}\text { Cost of Production } \\
(\text { USD ha-1) }\end{array}$} & \multicolumn{2}{|c|}{$\begin{array}{l}\text { Gross Return } \\
\left(\text { USD ha }{ }^{-1}\right)\end{array}$} & \multicolumn{2}{|c|}{$\begin{array}{l}\text { Net Benefit } \\
\left(\text { USD ha }{ }^{-1}\right)\end{array}$} \\
\hline & 2017-2018 & 2018-2019 & $2017-2018$ & 2018-2019 & $2017-2018$ & 2018-2019 \\
\hline Weedy check & 459.2 & 467.5 & 351.1 & 503.6 & $-108.1(-113.0 \%)$ & $36.1(-94.4 \%)$ \\
\hline Weed-free check & 667.5 & 675.8 & 1499.3 & 1317.0 & 831.8 & 641.2 \\
\hline Pendimethalin & 493.4 & 501.7 & 1141.1 & 1221.8 & $647.7(-22.1)$ & $720.1(+12.3 \%)$ \\
\hline Pendimethalin $\mathrm{fb}$ Carfen + isop & 532.0 & 540.4 & 1575.7 & 1586.9 & $1043.7(+25.5 \%)$ & $1046.5(+63.2 \%)$ \\
\hline Carfen + isop & 497.8 & 506.1 & 1364.4 & 1388.1 & $866.6(+4.2 \%)$ & $882.0(+37.6 \%)$ \\
\hline
\end{tabular}

$\mathrm{fb}=$ followed by, Carfen + isop = carfentrazone-ethyl + isoproturon. USD 1 = BDT 84 (approximately). Input cost: Market rate herbicides: pendimethalin $=$ USD $30.06 \mathrm{ha}^{-1}$ and carfentrazone-ethyl + isoproturon $=$ USD 34.46 ha $^{-1}$, Manual weeding cost: 50 laborers ha ${ }^{-1}$ for 2 weeding (weed free check plots); USD 4.17 labour $^{-1} \mathrm{day}^{-1}$, Herbicide application cost: 1 laborer ha ${ }^{-1}$ round $^{-1}$, wage USD $^{4.17}$ labor $^{-1}$ day $^{-1}$, Market price of wheat seeds: USD 89.29 ton $^{-1}$. Output cost: Market price of grain: USD 328.57 ton ${ }^{-1}$, Market price of straw: USD

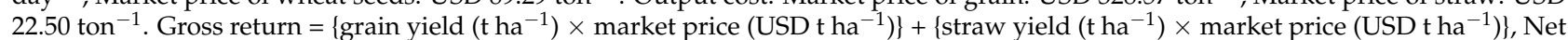
benefit $=$ Gross income - Total costs .

\subsection{Effect of Herbicides on Weeds in Rainy Season Rice}

The field of rainy season rice was affected by 11 weed species during 2018, among them, five were grasses (Cynodon dactylon (L.) Pers., Leptochloa chinensis (L.) Nees, Echinochloa colonum (L.) Link, Leersia hexandra (Sw.) and Paspalum commersonii (Lam.)), one sedge (Fimbristylis miliacea (L.) Vahl) and five broadleaf weeds (Ludwigia decurrens Walter, Jussiaea repens (L.), Monochoria vaginalis (Burm.f.) C. Presl ex Kunth, Enhydra fluctuants (Lour) and Alternanthera sessilis (L.) R.Br. ex DC.). The most dominant weed species of non-puddled transplanted rainy season rice was LEFCH (Table 9). During 2019, 12 weed species were counted in the experimental plots, of which five were identified as grassy (C. dactylon (L.), L. chinensis (L.), E. colonum (L.), L. hexandra (Sw.) and Sporobolus tremulus (Trin.) (Kunth), one sedge (F. miliacea (L.) and six broadleaf weeds (L. decurrens, J. repens, E. fluctuans, A. sessilis, Commelina benghalensis L. and Lindernia procumbens (Krock.) Philcox)). Among them, ALRSE emerged as the most dominant weed species (40.1\%) in the second season of the study (Table 9). 
Table 9. Infesting weed species in weedy check plots of T. aman rice recorded at 35 DAT under conservation agriculture systems in both years.

\begin{tabular}{|c|c|c|c|c|c|c|}
\hline \multirow{2}{*}{ Weed Species } & \multirow{2}{*}{ English Name } & \multirow{2}{*}{ EPPO Code } & \multirow{2}{*}{ Family } & \multirow{2}{*}{ Life Cycle } & \multicolumn{2}{|c|}{$\begin{array}{c}\% \text { Weed Infestation (Based on } \\
\text { Weed Density) }\end{array}$} \\
\hline & & & & & 2018 & 2019 \\
\hline \multicolumn{7}{|c|}{ Grass } \\
\hline Cynodon dactylon & Bermuda grass & CYNDA & Poaceae & Perennial & 7.6 & 15.7 \\
\hline $\begin{array}{l}\text { Leptochloa } \\
\text { chinensis }\end{array}$ & Asian sprangletop & LEFCH & Poaceae & Annual/Perennial & 19.8 & 8.9 \\
\hline $\begin{array}{l}\text { Echinochloa } \\
\text { colonum }\end{array}$ & Jungle rice & $\mathrm{ECHCO}$ & Poaceae & Annual & 13.0 & 1.6 \\
\hline Leersia hexandra & Swamp rice grass & LERHE & Poaceae & Annual/Perennial & 5.4 & 15.1 \\
\hline $\begin{array}{c}\text { Paspalum } \\
\text { commersonii }\end{array}$ & Paspalum grass & PASSC & Poaceae & Annual & 2.3 & - \\
\hline $\begin{array}{l}\text { Sporobolus } \\
\text { tremulus }\end{array}$ & Seed thrower grass & SPZTR & Poaceae & Annual & - & 6.4 \\
\hline \multicolumn{7}{|c|}{ Sedge } \\
\hline $\begin{array}{l}\text { Fimbristylis } \\
\text { miliacea }\end{array}$ & Grasslike fimbry & FIMMI & Cyperaceae & Annual/Perennial & 5.4 & 0.3 \\
\hline \multicolumn{7}{|c|}{ Broadleaf } \\
\hline Ludwigia decurrens & Willow primrose & IUSDE & Onagraceae & Annual & 15.2 & 1.9 \\
\hline Jussiaea repens & Water primrose & LUDAC & Onagraceae & Perennial & 7.6 & 2.2 \\
\hline Monochoria vaginalis & Pickerelweed & MOOVA & Pontederiaceae & Annual/Perennial & 1.1 & - \\
\hline Enhydra fluctuans & Water spinach & - & Asteraceae & Perennial & 8.4 & 6.4 \\
\hline Alternanthera sessilis & Dwarf copperleaf & ALRSE & Amaranthaceae & Perennial & 14.2 & 40.1 \\
\hline Commelina benghalensis & Tropical spiderwort & COMBE & Commelinaceae & Annual & - & 0.9 \\
\hline Lindernia procumbens & Lindernia grass & LIDPY & Scrophulariaceae & Annual & - & 0.4 \\
\hline
\end{tabular}

Herbicide treatments had a significant effect on the density of all types of weeds especially on grass and broadleaf weeds $(p \leq 0.001)$ (Figure 5$)$. The highest density of grass (59 plants $\mathrm{m}^{-2}$ in 2018 and 199 plants $\mathrm{m}^{-2}$ in 2019), sedge (7 plants $\mathrm{m}^{-2}$ in 2018 and 2 plants $\mathrm{m}^{-2}$ in 2019) and broadleaf weeds (57 plants $\mathrm{m}^{-2}$ in 2018 and 213 plants $\mathrm{m}^{-2}$ in 2019) were counted from 'weedy check' plots. The application of herbicides reduced the density of grasses by $26-89 \%$, sedge weeds by $60-100 \%$ and broadleaf weeds by $70-93 \%$ in the first season compared to the 'weedy check'. During the second year, the reduction was $74-100 \%$ for grasses, $100 \%$ for sedge and $75-100 \%$ for broadleaf weeds. Among these herbicides, pyrazosulfuron-ethyl followed by bispyribac-sodium reduced the maximum density of all weed species compared to the 'weedy check' and the lowest reduction was obtained from the sole application of pretilachlor as pre-emergence treatment (Figure 5). Zahan et al. [24] also identified the pyrazosulfuron-ethyl as the most effective pre-emergence herbicide for un-puddled transplanted rainy season rice. Similarly, Islam et al. [25] and Singh et al. [51] also obtained efficient weed control efficiency by application of the same herbicide in rainy season rice.

The application of all herbicides significantly reduced the total density and biomass of all weeds (Table 10). Among these, herbicide pyrazosulfuron-ethyl followed by bispyribacsodium offered the highest reduction in total weed density (92\%) and biomass (87\%) for 2018 and $100 \%$ for 2019 . However, the sole application of pretilachlor gave the lowest reduction in total weed density and the maximum biomass. Zahan et al. [52] and Chauhan et al. [53] also reported that sequential application of pre-and post-emergence herbicides were found the most effective for controlling weeds in un-puddled rainy season rice than the sole application of any herbicide. It might be due to the presence of crop residues, preemergence herbicides might not work effectively in CA, as crop residues might interrupt the applied herbicides [36], because of the interaction between the pre-emergence herbicides and residues on weed population dynamics. As the scope for application of pre-emergence herbicide in CA is limited, the application timing of post-emergence herbicides is crucial to reduce weed competition. In this regard, the rotation of herbicides and mixing different herbicides are known as effective measures of weed management in CA resulting in a delay in the development of herbicide resistance in weeds and management of weed population dynamics [54]. 
$\underline{2018}$
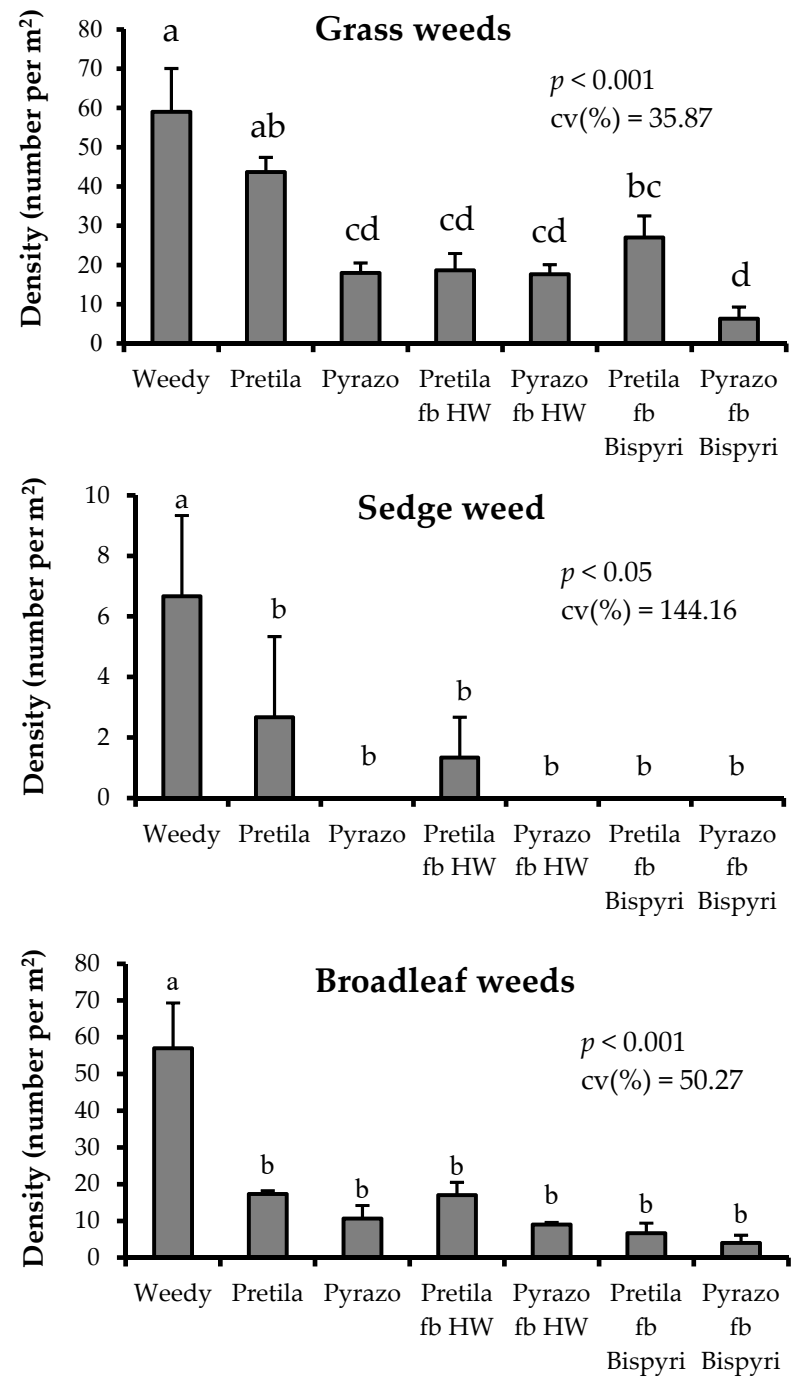

$\underline{2019}$
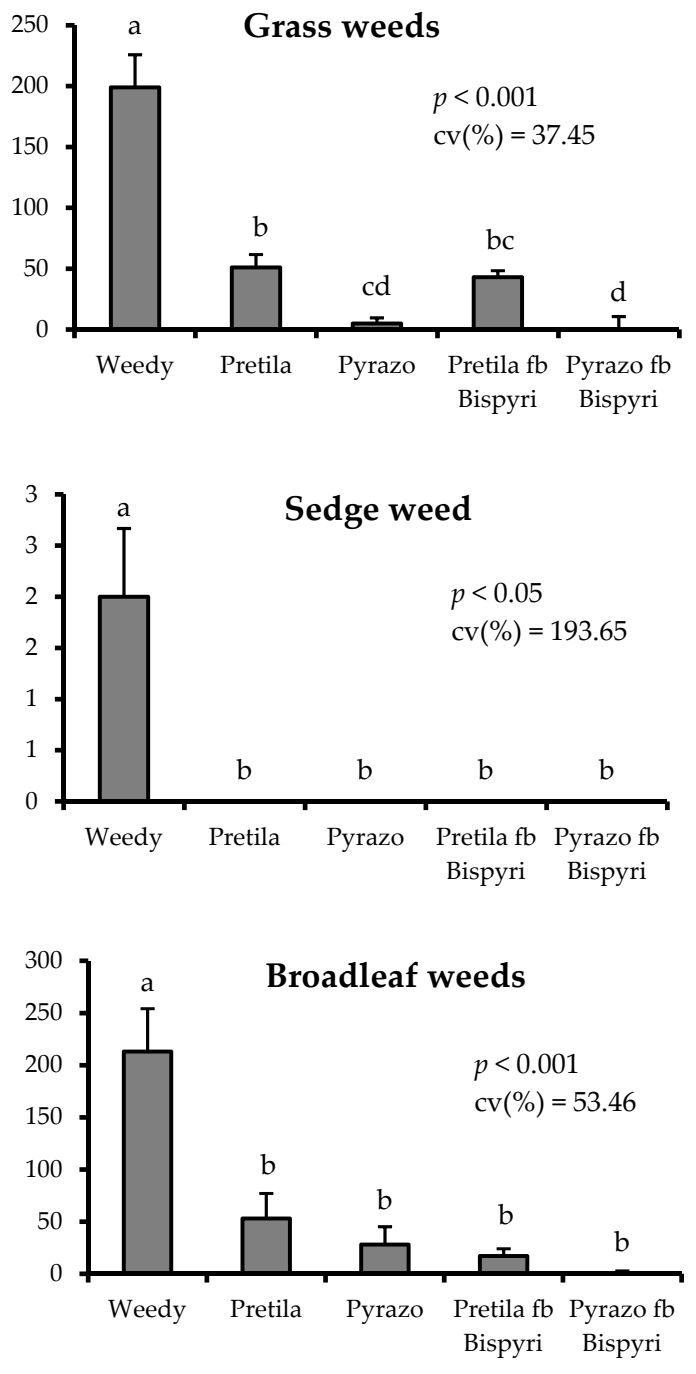

Figure 5. Effect of herbicides on the density of grass, sedge and broadleaf weeds at 40 DAT in the un-puddled transplanted rainy season rice in both seasons. (Here, preti = pretilachlor, $\mathrm{HW}=$ hand weeding, bispyr = bispyribac-sodium, Pyrazo = pyrazosulfuron.). Different small letters indicate statistically significant differences.

Table 10. Effect of herbicides on total weed density and total weed biomass at 40 days after transplanting of non-puddled rainy season rice under conservation agricultural systems in 2018 and 2019 at Gazipur, Bangladesh.

\begin{tabular}{|c|c|c|c|c|}
\hline \multirow{2}{*}{ Treatments } & \multicolumn{2}{|c|}{$\begin{array}{l}\text { Total Weed Density } \\
\left(\text { no. } \mathrm{m}^{-2}\right)\end{array}$} & \multicolumn{2}{|c|}{$\begin{array}{c}\text { Total Weed Dry } \\
\text { Biomass }\left(\mathrm{g} \mathrm{m}^{-2}\right)\end{array}$} \\
\hline & 2018 & 2019 & 2018 & 2019 \\
\hline Weedy check & $122.7 \mathrm{a}$ & $416.0 \mathrm{a}$ & $83.85 \mathrm{a}$ & $78.09 \mathrm{a}$ \\
\hline Pretilachlor & $63.7 \mathrm{~b}$ & $104.3 \mathrm{~b}$ & $37.13 \mathrm{~b}$ & $25.13 \mathrm{~b}$ \\
\hline Pyrazosulfuron-ethyl & $28.7 \mathrm{bc}$ & $33.3 \mathrm{~cd}$ & $22.28 \mathrm{c}$ & $9.94 \mathrm{~cd}$ \\
\hline Pretilachlor fb bispyribac & $33.7 \mathrm{bc}$ & $60.0 \mathrm{bc}$ & $13.81 \mathrm{c}$ & $16.22 \mathrm{bc}$ \\
\hline Pyrazosulfuron-ethyl fb bispyribac & $10.3 \mathrm{c}$ & $0.0 \mathrm{~d}$ & $10.85 c$ & $0.00 \mathrm{~d}$ \\
\hline F-Test & $* * *$ & $* * *$ & $* * *$ & $* * *$ \\
\hline $\mathrm{CV}(\%)$ & 37.66 & 34.51 & 20.24 & 19.27 \\
\hline
\end{tabular}

bispyribac $=$ bispyribac-sodium, $C V=$ co-efficient of variance, ${ }^{* * *}=0.1 \%$ level of significance. 


\subsection{Effect of Herbicides on Yield Contributing Characters, Yield and Economics of Rainy Season Rice}

Yield attributes and yield of un-puddled transplanted rainy season rice were significantly affected by different herbicides (Table 11).

Table 11. Effect of herbicides on yield and yield attributes of non-puddled transplanted rainy season rice in both seasons.

\begin{tabular}{|c|c|c|c|c|c|c|c|c|}
\hline \multirow{2}{*}{ Treatments } & \multicolumn{2}{|c|}{ Tillers (no. $\mathrm{m}^{-2}$ ) } & \multicolumn{2}{|c|}{$\begin{array}{c}\text { Effective Tillers (no. } \\
\mathbf{m}^{-2} \text { ) }\end{array}$} & \multicolumn{2}{|c|}{$\begin{array}{l}\text { Filled Grains } \\
\text { Panicle }^{-1} \text { (No.) }\end{array}$} & \multicolumn{2}{|c|}{ Grain Yield (t ha ${ }^{-1}$ ) } \\
\hline & 2018 & 2019 & 2018 & 2019 & 2018 & 2019 & 2018 & 2019 \\
\hline Weedy check & $271 \mathrm{~d}$ & $293 c$ & $261 c$ & $241 \mathrm{~d}$ & $120 \mathrm{c}$ & $159 \mathrm{~b}$ & 4.88 e $(-36.0 \%)$ & $4.22 \mathrm{~d}(-40.1 \%)$ \\
\hline Weed-free check & $304 \mathrm{ab}$ & $335 \mathrm{ab}$ & $302 \mathrm{ab}$ & $312 \mathrm{ab}$ & $141 \mathrm{~b}$ & $170 \mathrm{ab}$ & $7.62 \mathrm{~b}$ & $7.04 \mathrm{a}$ \\
\hline Preti & $283 \mathrm{~cd}$ & $305 \mathrm{bc}$ & $280 \mathrm{bc}$ & $274 \mathrm{c}$ & $139 \mathrm{~b}$ & $160 \mathrm{~b}$ & $6.09 \mathrm{~d}(-20.1 \%)$ & $5.21 \mathrm{c}(-26.0 \%)$ \\
\hline Pyrazo & 291 bc & $344 \mathrm{a}$ & $287 \mathrm{ab}$ & $304 \mathrm{abc}$ & $149 \mathrm{ab}$ & $177 \mathrm{ab}$ & 6.72 c $(-11.8 \%)$ & $6.08 \mathrm{~b}(-13.6 \%)$ \\
\hline Preti fb bispyr & $306 \mathrm{ab}$ & $316 \mathrm{bc}$ & $301 \mathrm{ab}$ & $282 \mathrm{bc}$ & $149 \mathrm{ab}$ & $170 \mathrm{ab}$ & $7.56 \mathrm{~b}(-0.8 \%)$ & $5.74 \mathrm{~b}(-18.5 \%)$ \\
\hline Pyrazo fb bispyr & 310 a & $351 \mathrm{a}$ & 307 a & $332 \mathrm{a}$ & $156 \mathrm{a}$ & $182 \mathrm{a}$ & 8.36 a $(+9.7 \%)$ & $7.36 \mathrm{a}(+4.5 \%)$ \\
\hline F-Test & $* *$ & $* *$ & $* *$ & $* * *$ & $* * *$ & $* *$ & $* * *$ & $* * *$ \\
\hline CV (\%) & 3.25 & 3.79 & 4.19 & 4.29 & 4.40 & 6.88 & 3.17 & 3.91 \\
\hline
\end{tabular}

In the column, means with similar letter(s) are statistically identical as per $\mathrm{LSD}_{0.05}$. Here, preti = pretilachlor, $\mathrm{HW}=\mathrm{hand}$ weeding, bispyr $=$ bispyribac-sodium, Pyrazo $=$ pyrazosulfuron; $C V=$ co-efficient of variance, ${ }^{* * *}=0.1 \%$ level of significance, ${ }^{* *}=1 \%$ level of significance. Values within the parenthesis '()' express the percentage of change in grain yield over the weed-free check.

The maximum grain yield was obtained from the pyrazosulfuron-ethyl applied treatments followed by bispyribac-sodium treated plots in both years; it is due to the contribution of the highest tillers and effective tillers, filled grains panicle ${ }^{-1}$ and the longest panicle, while the least values in terms of tillers and heads $\mathrm{m}^{-2}$, filled grains panicle ${ }^{-1}$ and grain yield were noted with the 'weedy check' plots. It is due to efficient control of most of the weeds, which lead to proper growth and development of crops [55,56].

The economic analysis results showed that the application of sole herbicide or herbicides in the sequence offered more economic profit than manual weeding $(6-38 \%)$ in 2018 and $0.3-36 \%$ in 2019 (Table 12). The maximum net benefit was calculated from the pyrazosulfuron-ethyl and bispyribac-sodium applied plots, whereas the sole application of pretilachlor gave the minimum benefit. The reason for getting the least profit from pretilachlor might be related to poor weed control that restricts the production of desirable grain and straw yields.

Table 12. Economic performance of herbicides in un-puddled T. aman rice in both years.

\begin{tabular}{ccccccc}
\hline \multirow{2}{*}{ Treatments } & \multicolumn{2}{c}{$\begin{array}{c}\text { Cost of Production } \\
\text { (USD ha }\end{array}$} & \multicolumn{2}{c}{$\begin{array}{c}\text { Gross Return } \\
\text { (USD ha }\end{array}$} & \multicolumn{1}{c}{ ) } & \multicolumn{2}{c}{$\begin{array}{c}\text { Net Benefit } \\
\text { (USD ha }\end{array}$} \\
\cline { 2 - 7 } & $\mathbf{2 0 1 8}$ & $\mathbf{2 0 1 9}$ & $\mathbf{2 0 1 8}$ & $\mathbf{2 0 1 9}$ & $\mathbf{2 0 1 8}$ & $\mathbf{2 0 1 9}$ \\
\hline Weedy check & 557.5 & 558.1 & 1346.9 & 1193.9 & $789.4(-36.0 \%)$ & $635.8(-40.2)$ \\
Weed-free check & 870.0 & 870.6 & 2104.3 & 1934.2 & 1234.3 & 1063.6 \\
Preti & 571.1 & 571.7 & 1715.7 & 1480.4 & $1144.6(-7.3 \%)$ & $908.8(-14.6)$ \\
Pyrazo & 566.3 & 566.9 & 1872.4 & 1710.9 & $1306.1(+5.8 \%)$ & $1144.0(+7.6 \%)$ \\
Preti fb bispyri & 582.4 & 583.0 & 2094.1 & 1649.9 & $1511.7(+22.5)$ & $1067.0(+0.3 \%)$ \\
Pyrazo fb bispyri & 577.6 & 578.2 & 2283.4 & 2026.5 & $1705.8(+38.2)$ & $1448.3(+36.2 \%)$ \\
\hline
\end{tabular}

$\mathrm{fb}=$ followed by, Preti = pretilachlor, Pyrazo = pyrazosulfuron-ethyl, bispyri = bispyribac-sodium. Input cost: Market price of commercial herbicides: pretilachlor = USD $9.40 \mathrm{ha}^{-1}$, pyrazosulfuron-ethyl = USD $4.64 \mathrm{ha}^{-1}$ and bispyribac-sodium = USD 7.14 ha ${ }^{-1}$, Manual weeding cost: 75 laborers ha ${ }^{-1}$ for 3 weeding (weed free check plots), wage rate: USD 4.17 labor $^{-1}$ day $^{-1}$, Herbicide application cost: 1 laborer ha ${ }^{-1}$ round ${ }^{-1}$, wage rate: USD 4.17 labor $^{-1}$ day $^{-1}$, Market price of rice seeds: USD 19.05 ton $^{-1}$ in 2018 and USD 23.81 ton $^{-1}$ in 2019. Output cost: Market price of grain: USD 214.29 ton $^{-1}$, Market price of straw: USD29.76 ton $^{-1}$. USD 1 = BDT 84 (approximately).

\section{Conclusions}

As weed management is vital in the conservation agricultural (CA) system, the findings of this study revealed that the weeds of wheat and rainy season rice can effectively be controlled by sequential application of various herbicides under the CA-based wheatmung bean-rice cropping pattern. The study concluded that all types of weeds in strip- 
planted wheat were controlled by sequential application of pendimethalin as pre-emergence treatment followed by carfentrazone-ethyl plus isoproturon as post-emergence herbicide. Consequently, maximum grain and straw yields were attained from this treatment. In non-puddled rainy season rice, the treatment with pyrazosulfuron-ethyl as pre-emergence application followed by bispyribac-sodium as the post-emergence herbicide managed weeds most effectively and economically with the desired yield.

Author Contributions: Conceptualization, T.Z., M.F.H., A.K.C., M.O.A. and M.A.A.; Methodology, T.Z., M.F.H. and A.K.C.; Software, T.Z. and A.H.; Validation, T.Z., M.F.H., A.K.C., M.O.A. and M.A.A.; Formal analysis, T.Z. and A.H.; Investigation, T.Z.; Resources, A.K.C. and M.A.A.; Data curation, T.Z. and A.H.; Writing—original draft preparation, T.Z., M.F.H., A.K.C., M.O.A. and M.A.A.; Writingreview and editing, A.H., S.M., E.S.D. and M.M.H.; Visualization, T.Z.; Supervision, A.K.C. and M.A.A.; Project administration, M.A.A., E.S.D. and M.M.H. Funding acquisition, A.H., E.S.D. and M.M.H. All authors have read and agreed to the published version of the manuscript.

Funding: The research work was funded by Taif University Researchers Supporting Project (TURSP2020/85), Taif University, Taif, Saudi Arabia.

Institutional Review Board Statement: Not applicable.

Informed Consent Statement: Not applicable.

Data Availability Statement: Most of the recorded data are available in Tables and Figures of the manuscripts.

Acknowledgments: The authors extend their appreciation to Bangladesh Agricultural Research Institute for providing the physical supports in research activities. The authors also extend their appreciation to Researchers Supporting Project (TURSP-2020/85), Taif University, Taif, Saudi Arabia.

Conflicts of Interest: The authors declare no conflict of interest.

\section{References}

1. FAO (Food and Agriculture Organization of the United Nations). Save and Grow, a Policymaker's Guide to Sustainable Intensification of Smallholder Crop Production; FAO: Rome, Italy, 2011; 116 p.

2. Salahin, N.; Alam, K.; Mondol, A.T.A.M.I.; Islam, M.S.; Rashid, M.H.; Hoque, M.A. Effect of tillage and residue retention on soil properties and crop yields in wheat-mungbean-rice crop rotation under subtropical humid climate. Open J. Soil Sci. 2017, 7, 1-7. Available online: http:/ / www.scirp.org/journal/ojss (accessed on 25 July 2021).

3. Kushwaha, C.P.; Tripathi, S.K.; Singh, K.P. Soil organic matter and water-stable aggregates under different tillage and residue conditions in a tropical dry land agro-ecosystem. Appl. Soil Ecol. 2001, 16, 229-241. [CrossRef]

4. Kumar, N.B.T.; Babalad, H.B. Influence of conservation agriculture practices on biological soil quality. Int. J. Curr. Microbiol. App. Sci. 2018, 7, 312-322. [CrossRef]

5. Bell, R.W.; Haque, M.E. Conservation agriculture and mechanization for smallholder agriculture: A win-win for agriculture and the environment. In 2nd Conference on Conservation Agriculture for Smallholders (CASH-II); Bell, R.W., Vance, W., Haque, M.E., Jahiruddin, M., Hashem, A., Brennan, R., Rahman, M.M., Eds.; Bangladesh Agricultural University: Mymensingh, Bangladesh, 2017; pp. 6-7.

6. Congreves, K.A.; Hayes, A.; Verhallen, L.L.; Van Eerd, L.L. Long term impact of tillage and crop rotation on soil health at four temperate agroecosystems. Soil Tillage Res. 2015, 152, 17-28. [CrossRef]

7. Corsi, S.; Muminjanov, H. Conservation Agriculture: Training Guide for Extension Agents and Farmers in Eastern Europe and Central Asia; FAO: Rome, Italy, 2019; 123 p.

8. Frąc, M.; Hannula, S.E.; Bełka, M.; Jędryczka, M. Fungal Biodiversity and Their Role in Soil Health. Front. Microbiol. 2018, 9, 707. [CrossRef]

9. Hou, D.; Bolan, N.S.; Tsang, D.C.W.; Kirkham, M.B.; O'Connor, D. Sustainable soil use and management: A interdisciplinary and systematic approach. Sci. Total Environ. 2020, 10, 729. [CrossRef]

10. Huera-Lucero, T.; Labrador-Moreno, J.; Blanco-Salas, J.; Ruiz-Téllez, T. A Framework to incorporate biological soil quality indicators into assessing the sustainability of territories in the Ecuadorian Amazon. Sustainability 2020, 12, 3007. [CrossRef]

11. Lehman, R.M.; Cambardella, C.A.; Stott, D.E.; Acosta-Martinez, V.; Manter, D.K.; Buyer, J.S.; Maul, J.E.; Smith, J.L.; Collins, H.P.; Halvorson, J.J.; et al. Understanding and enhancing soil biological health: The solution for reversing soil degradation. Sustainability 2015, 7, 988-1027. [CrossRef]

12. Rojas, R.V.; Moujahed, A.M.; Maroulis, J.; Caon, L. Healthy soils: A prerequisite for sustainable food security. Environ. Earth Sci. 2016, 75, 180. [CrossRef] 
13. Bell, R.W.; Haque, M.E.; Jahiruddin, M.; Rahman, M.M.; Begum, M.; Miah, M.A.M.; Islam, M.A.; Hossen, M.A.; Salahin, N.; Zahan, T.; et al. Conservation agriculture for rice-based intensive cropping by smallholders in the Eastern Gangetic Plain (EGP). Agriculture 2018, 9, 5. [CrossRef]

14. Bell, R.W.; Haque, M.E.; Johansens, C.; Vance, W.; Kabir, M.E.; Musa, M.A.; Mia, M.N.N.; Neogi, M.G.; Islam, M.A. Mechanised minimum soil disturbance establishment and yield of diverse crops in paddy fields using a two-wheel tractor-mounted planter suitable for smallholder cropping. Exp. Agric. 2018, 54, 755-773. [CrossRef]

15. Islam, S.; Gathala, M.K.; Tiwari, T.P.; Timsina, J.; Laing, A.M.; Maharjan, S.; Chowdhury, A.K.; Bhattacharya, P.M.; Dhar, T.; Mitra, B.; et al. Conservation agriculture based sustainable intensification: Increasing yields and water productivity for smallholders of the Eastern Gangetic Plains. Field Crop. Res. 2019, 238, 1-17. [CrossRef]

16. Hossain, M.I.; Gathala, M.K.; Tiwari, T.P.; Hossain, M.S. Strip tillage seeding technique: A better option for utilizating residual soil moisture in rainfed moisture stress environments of north-west Bangladesh. Int. J. Recent Dev. Eng. Tech. 2014, 2, $132-136$.

17. Chaki, A.K.; Gaydon, D.S.; Dalal, R.C.; Bellotti, W.D.; Gathala, M.K.; Hossain, A.; Menzies, N.W. Puddled and zero-till unpuddled transplanted rice are each best suited to different environments-An example from two diverse locations in the Eastern Gangetic Plains of Bangladesh. Field Crop. Res. 2021, 262, 108031. [CrossRef]

18. Jorgensen, M.H. The Effect of Tillage on the Weed Control: An Adaptive Approach. In Biological Approaches for Controlling Weeds; Radhakrisnan, R., Ed.; InTech: London, UK, 2018; pp. 17-25. [CrossRef]

19. Weber, J.F.; Kunz, C.; Peteinatos, G.G.; Zikeli, S.; Gerhards, R. Weed Control Using Conventional Tillage, Reduced Tillage, No-Tillage, and Cover Crops in Organic Soybean. Agriculture 2017, 7, 43. [CrossRef]

20. Steckel, L.E.; Sprague, C.L.; Stoller, E.W.; Wax, L.M.; Simmons, F.M. Tillage, cropping system and soil depth effects on common waterhemp (Amaranthus rudis) seed-bank persistence. Weed Sci. 2007, 55, 235-239. [CrossRef]

21. Zahan, T.; Rahman, M.M.; Begum, M.; Muktadir, M.A.; Ferdous, M.Z.; Haque, M.E.; Bell, R.W. Weed control strategies for wheat (Triticum aestivum L.) in a cereal-legume cropping system on the old Brahmaputra floodplain, Bangladesh. J. Asian-Pac. Weed Sci. Soc. 2020, 2, 35-50.

22. Zahan, T.; Rahman, M.M.; Begum, M. Weed control efficacy of herbicides in wheat under strip tillage system. Fundam. Appl. Agric. 2016, 1, 92-96.

23. Derpsch, R.; Friedrich, T. Development and current status of no-till adoption in the world. In Proceedings of the 18th Triennial Conference of the International Soil Tillage Research Organization (ISTRO), Izmir, Turkey, 15-19 June 2009.

24. Zahan, T.; Bell, R.W.; Rahman, M.M.; Ahmed, M.M. Performance of pyrazosulfuron-ethyl in un-puddled transplanted rainy season rice and its residual effect on growth of the succeeding crop in rice-wheat cropping pattern. Int. J. Pest. Manag. 2020, 66, 122-130. [CrossRef]

25. Islam, A.K.M.M.; Popy, F.S.; Hasan, A.; Anwar, M.P. Efficacy and economics of herbicidal weed management in monsoon rice of Bangladesh. J. Sci. Agric. 2017, 1, 275-293. [CrossRef]

26. Hossain, A.; Chowdhury, M.A.S.; Malaker, P.K.; Mandal, M.S.N.; Sarker, M.A.Z. Efficacy and economics of herbicides against narrow and broad-leaved weeds of wheat. Bangladesh J. Weed Sci. 2010, 1, 71-79.

27. Hashem, A.; Bowran, D.; Piper, T.; Dhammu, H. Resistance of Wild Radish (Raphanus raphanistrum) to Acetolactate SynthaseInhibiting Herbicides in the Western Australia Wheat Belt. Weed Technol. 2001, 15, 68-74. [CrossRef]

28. Swanton, C.J.; Shrestha, A.; Clements, D.R.; Booth, B.D. Evaluation of alternative weed management systems in a modified no-tillage corn-soybean-winter wheat rotation: Weed densities, crop yield, and economics. Weed Sci. 2002, 50, 504-511. [CrossRef]

29. Kegode, G.O.; Forcella, F.; Cay, S. Influence of crop rotation, tillage, and management inputs on weed seed production. Weed Sci. 1999, 47, 175-183. [CrossRef]

30. Liebman, M.; Dyck, E. Crop rotation and intercropping strategies for weed management. Ecol. Appl. 1993, 3, 92-122. [CrossRef]

31. Schreiber, M.M. Influence of tillage, crop rotation, and weed management on giant foxtail (Setaria faberi) population dynamics and corn yield. Weed Sci. 1992, 40, 645-653. [CrossRef]

32. Timsina, J.; Connor, D.J. Productivity and management of rice-wheat cropping systems: Issues and challenges. Field Crop. Res. 2001, 69, 93-132. [CrossRef]

33. Hossain, M.I.; Hossain, M.I.; Mondal, M.R.I.; Sultan, M.K.; Gathala, M.; Tiwary, T.P. Long-term bed planting effect on stabilizing productivity of rice and wheat in a drought prone area of Bangladesh. Bangladesh Agron. J. 2014, 17, 23-32. [CrossRef]

34. Hossain, M.I. Nutrient and Residue Management for Improving Productivity and N Use Efficiency of Rice-Wheat-Mungbean Systems in Bangladesh; Annual Report; Regional Wheat Research Centre, Bangladesh Agricultural Research Institute: Gazipur, Bangladesh, 2009; pp. 1-10.

35. Montazeri, M.; Zand, E.; Baghestani, M.A. Weeds and Their Control in Wheat Fields of Iran, 1st ed.; Agricultural Research and Education Organization Press: Tehran, Iran, 2005.

36. Zahan, T.; Rahman, M.M.; Hashem, A.; Bell, R.W.; Begum, M. Efficacy of Herbicides in Non-puddled Transplanted Rice under conservation agriculture systems and their effect on establishment of the succeeding crops. Acta Sci. Malays. 2018, 2, 17-25. [CrossRef]

37. Ahmmed, S.; Jahiruddin, M.; Razia, S.; Biswas, J.C.; Rahman, A.S.M.M.; Ali, M.M.; Islam, K.M.S.; Hossain, M.M.; Gani, G.M.A.H.; Satter, M.A. Fertilizer Recommendation Guide-2018; Bangladesh Agricultural Research Council (BARC): Dhaka, Bengal, 2018; 223p.

38. R Core Team. A Language and Environment for Statistical Computing; R Foundation for Statistical Computing: Vienna, Austria, 2013; ISBN 3-900051-07-0. Available online: http:/ / www.R-project.org/ (accessed on 21 March 2021). 
39. Parvez, M.S.; Salam, M.A.; Kato-Noguchi, H.; Begum, M. Effect of cultivar and weeding regime on the performance of transplant aman rice. Int. J. Agric. Crop Sci. 2013, 6, 654-666.

40. Vidal, R.A.; Bauman, T.T. Surface wheat (Triticum aestivum) residues, giant foxtail (Setaria faberi), and soybean (Glycine max) yield. Weed Sci. 1996, 44, 939-943. [CrossRef]

41. Wicks, G.A.; Crutchfield, D.A.; Burnside, O.C. Influence of wheat (Triticum aestivum) straw mulch and metolachlor on corn (Zea mays) growth and yield. Weed Sci. 1994, 42, 141-147. [CrossRef]

42. Teasdale, J.R. Interaction of light, soil moisture, and temperature with weed suppression by hairy vetch residue. Weed Sci. 1993, 41, 46-51. [CrossRef]

43. Ngwira, A.; Aune, J.B.; Thierfelder, C. On-farm evaluation of the effects of the principles and components of conservation agriculture on maize yield and weed biomass in Malawi. Exp. Agric. 2014, 50, 591-610. [CrossRef]

44. Mashingaidze, N.; Madakadza, C.; Twomlow, S.; Nyamangara, J.; Hove, L. Crop yield and weed growth under conservation agriculture in semi-arid Zimbabwe. Soil Till. Res. 2012, 124, 102-110. [CrossRef]

45. Buhler, D.D.; Stoltenberg, D.E.; Becker, R.L.; Gunsolus, J.L. Perennial weed populations after 14 years of variable tillage and cropping practices. Weed Sci. 1994, 42, 205-209. [CrossRef]

46. Patterson, D.T. Effects of environmental stress on weed/crop interactions. Weed Sci. 1995, 43, 483-490. [CrossRef]

47. Chadha, A.; Florentine, S.K.; Chauhan, B.S.; Long, B.; Jayasundera, M. Influence of soil moisture regimes on growth, photosynthetic capacity, leaf biochemistry and reproductive capabilities of the invasive agronomic weed Lactuca serriola. PLoS ONE. 2019, 14, e0218191. [CrossRef]

48. Nichols, V.; Verhulst, N.; Cox, R.; Govaerts, B. Weed dynamics and conservation agriculture principles: A review. Field Crop. Res. 2015, 183, 56-68. [CrossRef]

49. Hamouz, P.; Hamouzová, K.; Novotná, K. Effects of spring herbicide treatments on winter wheat growth and grain yield. Sci. Agric. Bohem. 2015, 46, 1-6. [CrossRef]

50. Khalil, M.F.; Hassan, G.; Ahmed, G.; Anwar, S.; Khan, S. Comparative efficacy of herbicides on yield and yield components of wheat (TriticumaestivumL.). J. Agric. Biol. Sci. 2013, 8, 76-80.

51. Mukherejee, P.K.; Bhattacharya, P.M.; Chowdhury, A.K. Weed control in wheat (Triticum aestivumL.) under terai-agroecological region of West Bengal. J. Wheat Res. 2011, 3, 30-35.

52. Sims, B.; Corsi, S.; Gbehounou, G.; Kienzle, J.; Taguchi, M.; Friedrich, T. Sustainable Weed Management for Conservation Agriculture: Options for Smallholder Farmers. Agriculture 2018, 8, 118. [CrossRef]

53. Singh, A.; Singh, A.K.; Singh, S.B. Relative Efficacy of Herbicides for Weed Control in Rice: A Review. Int. J. Curr. Microbiol. App. Sci. Sci. 2020, 9, 2375-2382. [CrossRef]

54. Chauhan, B.S.; Awan, T.H.; Abugho, S.B.; Evengelista, G.; Yadav, S. Effect of crop establishment methods and weed control treatments on weed management and rice yield. Field Crop. Res. 2015, 172, 72-84. [CrossRef]

55. Chauhan, B.S.; Singh, R.G.; Mahajan, G. Ecology and management of weeds under conservation agriculture: A review. Crop Prot. 2012, 38, 57-65. [CrossRef]

56. Jena, T.; Meena, B.L. Weed management options in conservation agriculture. Int. J. Curr. Microbiol. App. Sci. 2017, 6, 1232-1244. [CrossRef] 